\title{
O Caminho da Inclusão de Pessoas com DeficiÊnCia no MERCADO de TRABalho: ondE ESTAMOS?
}

\author{
Alexandre Antonio Bruno da Silva* \\ André Studart Leitão** \\ Eduardo Rocha Dias***
}

\begin{abstract}
Introdução: a epopeia ignorada. 2. Normas Internacionais de Proteção ao Deficiente. 3. Legislação Brasileira de Proteção ao Deficiente. 4. Números da Inclusão no Brasil e Ceará. 5. Dados da Relação Anual de Informações Sociais (RAIS). 6. A atuação do Ministério do Trabalho e Previdência Social. 7. Considerações finais. Referências.
\end{abstract}

\section{RESUMO}

Nas últimas décadas, organizações internacionais, entes estatais, organizações não governamentais e a sociedade como um todo, lançaram seu olhar para a luta travada pelos deficientes, almejando sua inclusão social. Uma série de documentos internacionais foi criada, visando não só melhorar as condições de vida do deficiente, mas também colocar em pauta inclusão social. Cada ser humano tem o direito de desfrutar de todas as condições necessárias para o desenvolvimento de seus talentos e aspirações. O deficiente deve ter ao seu dispor condições especiais, além da proteção garantida a todos, que minimizem ou eliminem as barreiras para a sua vida em sociedade. A Convenção sobre os Direitos das Pessoas com Deficiência, ratificada pelo Brasil, teve como propósito maior promover, proteger e assegurar o pleno exercício dos direitos humanos das pessoas com deficiência, demandando dos Estados-partes medidas legislativas e administrativas. No âmbito legislativo brasileiro, após várias normas tratando do assunto, foi instituída a Lei Brasileira de Inclusão da Pessoa com Deficiência (Estatuto da Pessoa com Deficiência). Certamente, apesar de sua importância, a legislação não tem o poder de transformar

* Mestre em Direito pela UFC. Doutor em Direito pela PUC-SP. Auditor-Fiscal do Trabalho. Professor no Centro Universitário Christus. E-mail: < alexandre_bruno@terra.com.br>.

** Mestre e Doutor em Direito das Relações Sociais pela PUC-SP. Procurador Federal. Professor no Centro Universitário Christus. E-mail: <andrestudart@hotmail.com>.

***DDoutor em Direito pela Universidade de Lisboa. Mestre em Direito pela Universidade Federal do Ceará. Procurador Federal. Professor do Programa de Pós-Graduação em Direito da Universidade de Fortaleza. E-mail: <eduardordias@hotmail.com>. 
rapidamente o comportamento da sociedade. São necessárias políticas públicas, já previstas no próprio Estatuto, para estimular e acompanhar esse processo. A inclusão do deficiente no mundo do trabalho é uma das mais importantes vertentes desse esforço. Por meio dos números obtidos pelos sistemas de estatística existentes é possível: analisar o grau de sucesso, verificar onde as políticas públicas de inclusão apresentam falhas e sugerir mudanças.

Palavras-chave: Deficiência. Inclusão Social. Emprego. Censo. RAIS.

\section{INTRODUÇÃO: A EPOPEIA IGNORADA}

No âmbito dos direitos humanos, através da análise dos temas considerados prioritários, constata-se que as pessoas deficientes compõem a última minoria a receber atenção especial. São fartos os exemplos na história em que o contexto de exclusão social os serviu, por vezes, como único e fiel companheiro em sua silenciosa jornada.

O estudo exaustivo dessa "epopeia ignorada" foge do escopo temático do presente trabalho. ${ }^{1}$ Entretanto, parece importante tecer breves comentários sobre essa caminhada, criando-se um fio condutor dessa luta antiga e constante pela inclusão social. Nesse estudo, marcaremos três momentos, tendo como ponto central da análise, a causa da deficiência e as suas consequências práticas.

No primeiro momento, o deficiente foi considerado como alguém merecedor da sua deficiência, fruto de um castigo divino, produzido por vícios ou mazelas dos seus antepassados. ${ }^{2} \mathrm{O}$ surgimento do cristianismo no Império Romano, com a sua doutrina dirigida à caridade e ao amor, combateu, dentre outras práticas, a eliminação das crianças deficientes. A partir do século IV, surgem os primeiros hospitais e asilos de caridade que abrigavam indigentes e indivíduos com deficiências. ${ }^{3}$

Apesar da nobreza de seus atos, essa forma de lidar com os deficientes, abrigando e protegendo-os, terminou por exclui-los do convívio social. As ações que, em sua maioria, denotavam gestos baseados na compaixão e na caridade, nesse período, contribuíram muito para o afastamento do deficiente de sua família e da sociedade.

Desprezar a compaixão, enfim - a caridade cristã -, será ver que ela foi confundida com a pena, com um contágio do sofrimento, com uma abdicação de alguém que se deixa influenciar, invadir, pela infelicidade do outro, mas, ao mesmo tempo, continua desprezando o ser digno de pena, com uma atitude niilista, conservadora de tudo aquilo que só merece desaparecer. ${ }^{4}$ 
A partir da Revolução Industrial, iniciada no século XVIII, caracterizada pela passagem da manufatura à indústria mecânica, a questão da habilitação e da reabilitação da pessoa com deficiência para o trabalho ganha força. A malformação congênita e as doenças deixam de ser suas únicas causas visíveis. $O$ trabalho em condições precárias passa a ocasionar acidentes mutiladores e também doenças profissionais. Torna-se necessária a criação de um sistema de seguridade social mais eficiente.

No século XIX, finalmente, percebe-se uma grande mudança para os indivíduos com deficiência. Surge uma atenção especializada, e não só institucional, como os hospitais e abrigos. Iniciam-se estudos específicos para os problemas ligados a cada deficiência. As grandes guerras mundiais, no início do século $\mathrm{XX}$, geram diversos deficientes, forçando uma mudança no tratamento dado ao deficiente.

Se na primeira fase citada a deficiência era vista como um castigo divino, na segunda passa a ter uma conotação meramente física. Passa a ser tratada, possuindo causas diversas e explicações científicas. A pessoa deficiente está ligada a uma certa incapacidade e dependência. Encontra-se em uma situação de desvantagem, caracterizada pela discordância entre a capacidade de realização individual do sujeito e as expectativas deste ou do seu grupo social. ${ }^{5}$

Essa fase ficou caracterizada pelo modelo médico da deficiência, que apregoa que pessoas com deficiência são vistas como possuidoras de um corpo inferior. Desconectados das suas potencialidades e dos conceitos de autonomia e independência. $O$ foco principal do estudo está centrado em suas deficiências.

A moral, constituída sob o império da indústria, provoca má consciência naqueles que não estejam sujeitos às leis da produtividade em geral. Marginais são todos aqueles que vivem na impossibilidade da troca e que não toleram a cultura de consumo. Enfim, todos aqueles que não obedecem às leis do mercado. ${ }^{6}$

Sentindo-se à margem da sociedade, as pessoas com deficiência passaram a se organizar. Surge o modelo social da deficiência. Segundo essa visão, a deficiência não é necessariamente ligada a uma doença, mas consequência da interação entre características corporais do indivíduo e as condições sociais em que ele vive. É fruto da combinação de limitações impostas pelo corpo com alguma lesão, combinados a uma organização social pouco sensível à diversidade corporal. ${ }^{7}$

Ressalte-se que adotar o paradigma do modelo social não representa o abandono da reabilitação e dos tratamentos médicos. A consideração é que esses cuidados estão aquém da deficiência tratada. A terapêutica, ainda que relevante, não deve se sobrepor à garantia de educação, emprego, cultura, lazer e vida independente para as pessoas com deficiência.

Essa forma de ver a realidade mostra o papel da sociedade perante as pessoas com deficiência, ampliando a responsabilidade social. Esses indivíduos 
passam a ser vistos com potencialidades e com objetivos pela sociedade. Esta tem a obrigação de caminhar com o olhar focado nas potencialidades dessas pessoas, proporcionando-as novos caminhos, objetivando a sua inclusão.

Cada ser humano tem o direito de desfrutar de todas as condições necessárias para o desenvolvimento de seus talentos e aspirações, sem ser submetido a qualquer tipo de discriminação. Dessa forma, a pessoa deficiente deve ter a seu alcance, além da proteção geral garantida a todos, àquelas que tem por base minimizar ou eliminar as lacunas existentes entre as suas condições e as das pessoas sem deficiência.

\section{NORMAS INTERNACIONAIS DE PROTEÇÃO AO DEFICIENTE}

Visando à proteção específica do deficiente, a Assembleia Geral da ONU proclamou duas importantes declarações e uma resolução, na década de 1970: a Declaração dos Direitos das Pessoas com Retardo Mental, em 1971; a Declaração dos Direitos das Pessoas Deficientes, em 1975; e a Resolução n. 31/123, em 1976, declarando o ano de 1981 como o Ano Internacional das Pessoas Deficientes. ${ }^{9}$

A Declaração dos Direitos das Pessoas Deficientes, de 09 de dezembro de 1975, teve a sua relevância por trazer o conceito de "pessoa deficiente", assim como influenciar na concepção da expressão "pessoa portadora de deficiência", utilizada pela Constituição Federal de 1988. Segundo ela, pessoa deficiente seria aquela incapaz de satisfazer por si própria, no todo ou em parte, as necessidades de uma vida normal individual ou social, em resultado de deficiência, congênita ou não, nas suas faculdades físicas ou mentais. ${ }^{10}$

O Ano Internacional das Pessoas Deficientes surge como o grande marco para que países, seus governantes, a sociedade e as próprias pessoas com deficiência tomassem consciência da relevância do tema. $\mathrm{O}$ assunto ganha relevância, passam a ser tomadas providências para a prevenção da deficiência, a reabilitação, a acessibilidade, a igualdade de condições, a participação plena e a mudança de valores sociais visando à redução crescente de preconceitos e atitudes discriminatórias.

A Conferência Geral da Organização Internacional do Trabalho (OIT), verificando a importância do ano Internacional das Pessoas Deficientes, com o tema "Participação plena e igualdade", avaliou que seria oportuno um programa mundial de ação relativo às pessoas deficientes. Esse plano permitiria a adoção de medidas eficazes a nível nacional e internacional para atingir as metas da "participação plena" das pessoas deficientes na vida social e no desenvolvimento.

A partir desse entendimento, surge a Convenção OIT n ${ }^{\circ} 159$, sobre Reabilitação Profissional e Emprego de Pessoas Deficientes, concluída em Genebra, a $1^{\circ}$ de junho de 1983. O Congresso Nacional brasileiro aprovou a Convenção, por meio do Decreto Legislativo n ${ }^{\circ}$ 51, de 25 de agosto de 1989, depositando em 18 de maio de 1990, a Carta de Ratificação da Convenção. ${ }^{11}$ 
A Convenção defende que de acordo com as condições nacionais, experiências e possibilidades nacionais, cada País Membro formulará, aplicará e periodicamente revisará a política nacional sobre reabilitação profissional e emprego de pessoas deficientes. A finalidade dessa política é de assegurar que existam medidas adequadas de reabilitação profissional ao alcance de todas as categorias de pessoas deficientes e promover oportunidades de emprego para as pessoas deficientes no mercado regular de trabalho.

No âmbito das Américas, tem-se a Convenção Interamericana para a Eliminação de Todas as Formas de Discriminação contra as Pessoas Portadoras de Deficiência, conhecida como Convenção da Guatemala, assinada pelo Brasil em 1999, promulgada pelo Decreto n. ${ }^{0} 3.956$, de 08 de outubro de 2001. Incorporada ao sistema legislativo brasileiro com status de lei ordinária, define o termo "deficiência" como uma restrição física, mental ou sensorial, de natureza permanente ou transitória, que limita a capacidade de exercer uma ou mais atividades essenciais da vida diária, causada ou agravada pelo ambiente econômico e social. ${ }^{12}$

Ainda no âmbito internacional, a Convenção sobre os Direitos das Pessoas com Deficiência foi homologada pela Assembleia das Nações Unidas em 13 de dezembro de 2006, entrando em vigência em 3 de maio de 2008, data em que ultrapassou o mínimo de vinte ratificações. ${ }^{13}$

No Brasil, essa Convenção que foi aprovada, por meio do Decreto Legislativo n. 186, de 9 de julho de $2008^{14}$, conforme o procedimento previsto no $\S 3^{\circ}$ do art. $5^{\circ}$ da Constituição, obtendo equivalência de Emenda Constitucional. ${ }^{15} \mathrm{O}$ Governo brasileiro depositou o instrumento de ratificação dos referidos atos junto ao Secretário-Geral das Nações Unidas em $1^{\circ}$ de agosto de 2008. A Convenção foi promulgada pelo Decreto 6.949, de 25 de agosto de 2009. ${ }^{16}$

O texto apresenta uma definição inovadora de deficiência, compreendida como toda e qualquer restrição física, mental, intelectual ou sensorial, causada ou agravada por diversas barreiras, que limite a plena e efetiva participação na sociedade. A inovação está no reconhecimento explícito de que o meio ambiente econômico e social pode ser causa ou fator de agravamento de deficiência. A própria Convenção reconhece ser a deficiência um conceito em construção, que resulta da interação de pessoas com restrições e barreiras que impedem a plena e efetiva participação na sociedade em igualdade com os demais. A deficiência deve ser vista como o resultado da interação entre indivíduos e seu meio ambiente e não como algo que reside intrinsecamente no indivíduo. ${ }^{17}$

A Convenção surge como resultado da patente necessidade de garantir o respeito, a integridade, a dignidade e a liberdade das pessoas com deficiência. Por meio dela, defende-se a criação de leis, políticas e programas que atendam ao público deficiente dentro de suas características, promovendo a sua participação na sociedade e a sensibilização dos demais membros da sociedade para o processo de inclusão. 
Visando a garantir a eficácia dos direitos das pessoas com deficiência, foi instituído um sistema de monitorização internacional da aplicação da Convenção, no âmbito das Nações Unidas, executado pelo Comitê dos Direitos das Pessoas com Deficiência. Integra também o Protocolo Opcional, anexo à Convenção, o direito de os indivíduos ou grupo de indivíduos apresentarem queixas ao Comitê dos Direitos das Pessoas com Deficiência.

Além dos já citados, outro avanço trazido pela Convenção foi a alteração do modelo médico para o modelo social. Nele o fator limitante é o meio em que a pessoa está inserida e não a deficiência em si. Tal abordagem deixa claro que as deficiências não indicam, necessariamente, a presença de uma doença ou que o indivíduo deva ser considerado doente. Assim, a falta de acesso a bens e serviços deve ser solucionada de forma coletiva e com políticas públicas estruturantes para a equiparação de oportunidades.

Deficiência e pobreza são termos inter-relacionados. As pessoas mais pobres têm uma chance significativa de adquirir uma deficiência ao longo de suas vidas, sendo que a deficiência pode resultar em pobreza, considerando que as pessoas com deficiência sofrem discriminação e marginalização. A deficiência é associada com analfabetismo, nutrição precária, falta de acesso à água potável, baixo grau de imunidade, doenças e condições de trabalho perigosas e insalubres. ${ }^{18}$

O Brasil é um dos poucos países, que tem legislação específica tratando dos deficientes. Apesar disso, os deficientes brasileiros continuam a compor percentuais elevados nas estatísticas de exclusão social. Essa realidade é confirmada pela baixa presença de pessoas com deficiência nos setores básicos que promovem a inclusão.

Os números relativos ao acesso ao trabalho, por exemplo, comprovam essa realidade. Inicialmente apresentaremos a legislação protetiva no âmbito do direito trabalhista, para depois passarmos aos dados estatísticos.

\section{LEGISLAÇÃO BRASILEIRA DE PROTEÇÃO AO DEFICIENTE}

A Constituição Brasileira proíbe qualquer discriminação no tocante ao salário e a critérios de admissão do trabalhador portador de deficiência (art. $7^{\circ}, \mathrm{XXXI}, \mathrm{CF}$ ). Em relação às vagas, para exercício de atividade remunerada, prevê que legislação complementar reservará percentual dos cargos e empregos públicos para as pessoas portadoras de deficiência e definirá os critérios de sua admissão. ${ }^{19}$

Na Administração Pública Federal, a Lei no 8.112, de 11 de dezembro de 1990, que dispõe sobre o regime jurídico dos servidores públicos civis da União, assegura o direito das pessoas deficientes se inscreverem em concurso público para provimento de cargo, cujas atribuições sejam compatíveis com a deficiência de que são portadoras, sendo-lhes reservadas até 20\% (vinte por cento) das vagas oferecidas no concurso (artigo $5^{\circ}, \S 2^{\circ}$ ). ${ }^{20}$ 
O Decreto n ${ }^{0} 3.298$, de 20 de dezembro de 1999, estabelece que o percentual mínimo seja de $5 \%$ de reserva das vagas nos concursos públicos (artigo 37, § $1^{\circ}$ ), aplicando o arredondamento para o primeiro número inteiro subsequente, quando o resultado do percentual resultar em número fracionado $\left(\S 2^{\circ}\right) .^{21}$

$\mathrm{Na}$ esfera privada, atualmente a reserva de vagas é assegurada para empresas que possuam 100 (cem) ou mais empregados. As cotas reservadas variam entre 2\% (dois por cento) e 5\% (cinco por cento) de acordo com o número de trabalhadores da empresa. Além disso, as empresas não podem efetivar dispensa imotivada, quando esta representar o número mínimo de trabalhadores com deficiência que a empresa deve possuir, até a contratação de substituto em condições semelhantes $\left(\S 1^{\circ}\right)$. ${ }^{22}$

Tabela 1 - Cota obrigatória de empregados com deficiência por empresa.

\begin{tabular}{cc}
\hline N Empregados & Cota (\%) \\
\hline $100-200$ & 2,00 \\
$201-500$ & 3,00 \\
$501-1000$ & 4,00 \\
$>1000$ & 5,00 \\
\hline
\end{tabular}

Fonte: Art. 93, Lei 8.213/91.23

A Lei $n^{\circ} 7.853$, de 24 de outubro de 1989 , em seu artigo $8^{\circ}$, com as alterações definidas pela Lei 13.145/2015, tipificou como crime punível com reclusão de 2 (dois) a 5 (cinco) anos e multa obstar inscrição em concurso público ou acesso de alguém a qualquer cargo ou emprego público, em razão de sua deficiência e negar ou obstar emprego, trabalho ou promoção à pessoa em razão de sua deficiência. ${ }^{24}$

No contexto da responsabilidade social das empresas, insere-se, entre outras, a obrigação de contribuir e apoiar a qualificação de seus empregados. A Medida Provisória n ${ }^{\circ}$ 251, de 13 de junho de 2005, posteriormente convertida na Lei $n^{\circ} 11.180$, de 23 de setembro de 2005, com a inserção do $\S 5^{\circ}$ ao artigo 428 da Consolidação das Leis Trabalhistas (CLT) ${ }^{25}$, prevê a possibilidade de as empresas contratarem aprendizes com deficiência independente do limite de idade, buscando a promoção da qualificação profissionais, pelos empregadores. ${ }^{26}$

Outro importante avanço normativo em prol da deficiência foi conquistado após a edição da Lei Complementar 142, em 8 de maio de 2013, que regulamentou a concessão de aposentadoria da pessoa com deficiência segurada do Regime Geral de Previdência Social - RGPS de que trata o $§ 1^{\circ}$ do art. 201 da Constituição Federal. ${ }^{27}$ 
Apesar da importância das medidas legislativas anteriores, a Lei n ${ }^{\circ}$ 13.146, de 6 de julho de 2015, que institui a Lei Brasileira de Inclusão da Pessoa com Deficiência (Estatuto da Pessoa com Deficiência), é o mais completo diploma que trata da inclusão do deficiente. ${ }^{28}$ De acordo com o seu texto, é classificada como pessoa com deficiência aquela que tem impedimentos de longo prazo de natureza física, mental, intelectual ou sensorial, capazes de obstruir sua participação plena e efetiva na sociedade em igualdade de condições com as demais pessoas.

Constitui modo de inclusão da pessoa com deficiência no trabalho a colocação competitiva, em igualdade de oportunidades com as demais pessoas, nos termos da legislação trabalhista e previdenciária, na qual devem ser atendidas as regras de acessibilidade, o fornecimento de recursos de tecnologia assistiva e a adaptação razoável no ambiente de trabalho. ${ }^{29}$

A tônica do texto é a inclusão social das pessoas com deficiência, que deve ser favorecida por meio de políticas públicas ou iniciativas a cargo das empresas. No âmbito trabalhista, o Estatuto estabelece a importância da colocação competitiva do deficiente no mercado do trabalho. Para isso, força que sejam oferecidas ao trabalhador deficiente, recursos tecnológicos e a adaptação ao ambiente de trabalho.

A colocação competitiva da pessoa com deficiência pode ocorrer por meio de trabalho com apoio, observadas como diretrizes:

a) o atendimento prioritário à pessoa com deficiência com maior dificuldade de inserção;

b) provisão de suportes individualizados que atendam as necessidades específicas da pessoa com deficiência;

c) respeito ao perfil vocacional e ao interesse da pessoa com deficiência apoiada;

d) oferta de aconselhamento e de apoio aos empregadores, com vistas à definição de estratégias de inclusão e de superação de barreiras, inclusive atitudinais;

e) realização de avaliações periódicas;

f) articulação intersetorial das políticas públicas;

Ainda no escopo trabalhista, foi garantido o direito ao auxílio-inclusão para a pessoa com deficiência moderada ou grave que passe a exercer atividade remunerada, que a enquadre como segurado obrigatório do Regime Geral da Previdência Social. Além desses, também é devido àquele que tenha recebido, nos últimos 5 (cinco) anos, o benefício de prestação continuada e que exerça atividade remunerada que a enquadre como segurado obrigatório do Regime Geral da Previdência Social. ${ }^{30}$

Como marco negativo, podemos citar o veto do art. 93, que continha a previsão de que empresas que tivessem a seus serviços de 50 (cinquenta) a 99 (noventa e nove) empregados, seriam obrigadas a preencher seus cargos com pessoas com deficiência e com beneficiários reabilitados da Previdência Social, com 1 (um) empregado. O cumprimento dessa obrigação somente passaria a ser fiscalizada no prazo de 3 (três) anos. ${ }^{31}$ 
Esse dispositivo foi vetado, apesar do mérito da proposta, por se acreditar que a medida poderia gerar impacto relevante no setor produtivo, especialmente para empresas de mão de obra intensiva de pequeno e médio porte. Alega-se que essa inclusão acarretaria dificuldades no seu cumprimento e haveria a aplicação de multas que poderiam inviabilizar empreendimentos de ampla relevância social. ${ }^{32}$

Somente no estado do Ceará, mediante consulta ao Sistema de Indícios de Débito (IDEB), verifica-se que seriam criadas 1.972 (mil, novecentos e setenta e duas) vagas para deficientes. Pelo grande número de estabelecimentos atingidos, mesmo número de vagas a serem preenchidas, a inclusão de deficientes ganharia grande força, não só em termos quantitativos, mas em amplitude. Nas regras atuais, apenas 1.213 (mil, duzentas e treze) empresas devem ter empregados deficientes em seus quadros. ${ }^{33}$

Para estimular a aplicabilidade do sistema de proteção ao trabalho do deficiente, foi alterada a Lei de Licitações, ${ }^{34}$ permitindo o uso de margens de preferência para as empresas que comprovem ter bens e serviços produzidos ou prestados por empresas que comprovem cumprimento de reserva de cargos prevista em lei para pessoa com deficiência ou para reabilitado da Previdência Social. Além disso, é preciso que essas empresas atendam às regras de acessibilidade previstas na legislação. ${ }^{35}$

As exigências, que motivaram a margem de preferência, devem ser mantidas durante todo o período de execução do contrato. Cabe à administração fiscalizar o cumprimento dos requisitos de acessibilidade nos serviços e nos ambientes de trabalho. ${ }^{36}$

Outra preocupação do Estatuto da Pessoa com Deficiência foi a criação do Cadastro Nacional da Inclusão da Pessoa com Deficiência, com a finalidade de coletar e processar informações destinadas à formulação, gestão, monitoramento e avaliação das políticas públicas para as pessoas com deficiência e para a realização de estudos e pesquisas.

O Cadastro-Inclusão, será registro público eletrônico, que deverá disseminar informações georreferenciadas que permitam a identificação e a caracterização socioeconômica da pessoa com deficiência, bem como as barreiras que impedem a realização de seus direitos.

\section{NÚMEROS DA INCLUSÃO NO BRASIL E CEARÁ}

No Brasil, a investigação sobre pessoas deficientes foi incorporada, nos censos mais recentes, iniciando pelo Censo Demográfico 1991. ${ }^{37}$ A promulgação da Lei no 7.853, de 24 de outubro de 1989, trouxe, entre outras garantias legais, a obrigação de se incluir nos censos nacionais questões específicas sobre essa população. ${ }^{38}$ 
O Censo Demográfico 2000, possibilitou o incremento dos dados relativos à percepção que as pessoas deficientes tinham em relação às alterações nas suas capacidades de realização, no seu comportamento e na sua participação social. As questões formuladas privilegiaram o estudo das incapacidades como ponto de partida para a identificação das deficiências e do grau de comprometimento das condições físicas ou mentais. ${ }^{39}$

A formulação das questões foi produto do trabalho conjunto entre o Instituto Brasileiro de Geografia e Estatística (IBGE) e pela antiga Coordenadoria Nacional para Integração da Pessoa Portadora de Deficiência (CORDE) ${ }^{40}$ Coordenação que passou a ser a Secretaria Nacional de Promoção dos Direitos das Pessoas com Deficiência, órgão federal, responsável pela política de inclusão das pessoas com deficiência desde o advento da Lei $\mathrm{N}^{\mathrm{O}} 7.853 / 1989 .{ }^{41}$

Segundo o Censo 2000, aproximadamente 25 milhões de brasileiros declararam possuir alguma deficiência. Esse número significou um acentuado aumento percentual de deficientes em relação ao Censo anterior. Segundo o Censo de 1991, o percentual de deficientes era de 1,41\%. No Censo de 2000 o percentual de pessoas que se declaram com alguma deficiência saltou para $14,5 \%$ da população. ${ }^{42}$

Reputa-se que a principal razão para o grande número de pessoas que se declararam deficientes foi a alteração do parâmetro de deficiência. A partir do Censo 2000, passou-se a adotar no país o modelo social de deficiência. Além disso, é possível citar outros aspectos que ocasionam esse aumento, como o envelhecimento da população e a crescente violência urbana.

No Censo 2010 há um novo salto no número de deficientes. Chega-se ao número de 45,6 milhões que declararam ter ao menos um tipo de deficiência. Esse número corresponde a 23,9\% da população brasileira, valor bem acima dos 14,5\% obtidos no Censo de 2000. ${ }^{43}$

Além da mudança no método de investigação das deficiências, podem ter causado parte do aumento, novamente, as mudanças na estrutura etária da população do país. Entre os anos 2000 e 2010, teve-se uma queda de 5,52\% de pessoas no grupo de 0 a 14 anos; aumento de 3,99\% na faixa de 15 a 64 e aumento de $1,53 \%$ no grupo de 65 ou mais anos de idade.

Tabela 2 - População brasileira por faixa etária

\begin{tabular}{llllll}
\hline Faixa etária & 2000 & $\%$ & 2010 & $\%$ & Variação \\
\hline Mais de 65 anos & 9.935 .100 & 5,85 & 14.081 .480 & 7,38 & $1,53 \%$ \\
15 a 64 anos & 109.597 .948 & 64,55 & 130.742 .024 & 68,54 & $3,99 \%$ \\
00 a 14 anos & 50.266 .122 & 29,60 & 45.932 .295 & 24,08 & $-5,52 \%$ \\
Total & 169.799 .170 & 100,00 & 190.755 .799 & 100,00 & \\
\hline
\end{tabular}


Segundo o próprio levantamento, o envelhecimento da população tem reflexo direto no número das pessoas que se declaram com alguma deficiência. Isso pode ser observado facilmente por meio da tabela de incidência de deficiência, segundo a faixa etária.

Tabela 3 - Tabela de incidência de deficiência por faixa etária

\begin{tabular}{ccccc}
\hline & $\begin{array}{c}\text { Deficiência } \\
\text { Visual }\end{array}$ & $\begin{array}{c}\text { Deficiência } \\
\text { Auditiva }\end{array}$ & $\begin{array}{c}\text { Deficiência } \\
\text { Motora }\end{array}$ & $\begin{array}{c}\text { Deficiência } \\
\text { Intelectual }\end{array}$ \\
\hline 0 a 14 anos & $5,30 \%$ & $1,30 \%$ & $1,00 \%$ & $0,90 \%$ \\
15 a 64 anos & $20,10 \%$ & $4,20 \%$ & $5,70 \%$ & $1,40 \%$ \\
Acima de 65 nos & $49,80 \%$ & $25,60 \%$ & $38,30 \%$ & $2,90 \%$ \\
\hline
\end{tabular}

No Censo de 2010, os dados foram coletados considerando que existe uma prevalência de certos diferentes tipos de deficiência, que ocorrem em diferentes graus de severidade, nos diversos segmentos da população.

Foram pesquisadas as deficiências visual, auditiva e motora, com seus respectivos graus de severidade, assim como a deficiência mental. Os diversos tipos de deficiência foram classificados pelo grau de severidade, de acordo com a percepção das próprias pessoas entrevistadas sobre as suas funcionalidades. Os graus de severidade utilizados foram os seguintes:

a) não consegue de modo algum;

b) grande dificuldade;

c) alguma dificuldade;

d) nenhuma dificuldade.

Em relação à deficiência mental ou intelectual, deveria ser indicado se a pessoa tinha alguma deficiência que limitasse as suas atividades habituais. A deficiência mental é definida como o retardo no desenvolvimento intelectual. É caracterizada pela dificuldade que a pessoa tem em se comunicar com outros, de cuidar de si mesma, de fazer atividades domésticas, de aprender, trabalhar, brincar etc.

A investigação dos graus de severidade de cada deficiência permite conhecer a parcela da população com deficiência severa. É esse conjunto de pessoas deficientes que se constitui no principal alvo das políticas públicas de inclusão. São consideradas com deficiência severa as pessoas que declararam as opções de resposta "grande dificuldade" ou "não consegue de modo algum" para as deficiências visual, auditiva e motora e aquelas que foram declaradas com deficiência mental. 
Tabela 4 - Deficiência no Brasil

\begin{tabular}{crcrcr}
\hline $\begin{array}{c}\text { Tipo de } \\
\text { deficiência }\end{array}$ & $\begin{array}{c}\text { Não con- } \\
\text { segue (A) }\end{array}$ & $\begin{array}{c}\text { Grande } \\
\text { dificuldade } \\
\text { (B) }\end{array}$ & $\begin{array}{c}\text { Alguma difi- } \\
\text { culdade (C) }\end{array}$ & $\begin{array}{c}\text { Deficiên- } \\
\text { cia severa } \\
(\mathrm{A}+\mathrm{B})\end{array}$ & $\begin{array}{c}\text { Deficiência } \\
\text { Severa / } \\
\text { População }\end{array}$ \\
\hline Física & 734.421 & 3.698 .929 & 8.832 .249 & 4.433 .350 & $2,32 \%$ \\
Auditiva & 344.206 & 1.798 .967 & 7.574 .145 & 2.143 .173 & $1,12 \%$ \\
Visual & 506.377 & 6.056 .533 & 29.211 .482 & 6.562 .910 & $3,44 \%$ \\
Intelectual & 2.611 .536 & & & 2.611 .536 & $1,37 \%$ \\
Totais & 4.196 .540 & 11.554 .429 & 45.617 .876 & 15.750 .969 & $8,26 \%$ \\
\hline
\end{tabular}

Fonte: Censo 2010.44

Tabela 5 - Deficiência no Estado do Ceará

\begin{tabular}{lccccc}
\hline $\begin{array}{c}\text { Tipo de } \\
\text { deficiência }\end{array}$ & $\begin{array}{c}\text { Não con- } \\
\text { segue }(\mathrm{A})\end{array}$ & $\begin{array}{c}\text { Grande } \\
\text { dificuldade } \\
(\mathrm{B})\end{array}$ & $\begin{array}{c}\text { Alguma } \\
\text { dificuldade } \\
(\mathrm{C})\end{array}$ & $\begin{array}{c}\text { Deficiên- } \\
\text { cia Severa } \\
(\mathrm{A}+\mathrm{B})\end{array}$ & $\begin{array}{c}\text { Deficiência } \\
\text { Severa / } \\
\text { População }\end{array}$ \\
\hline Física & 36.587 & 187.298 & 458.972 & 223.885 & $2,65 \%$ \\
Auditiva & 16.313 & 99.364 & 411.128 & 115.677 & $1,37 \%$ \\
Visual & 24.224 & 349.795 & 1.497 .949 & 374.019 & $4,43 \%$ \\
Intelectual & 125.353 & & & 125.353 & $1,48 \%$ \\
Totais & 202.477 & 636.457 & 2.368 .049 & 838.934 & $9,93 \%$ \\
\hline
\end{tabular}

Fonte: Censo 2010. ${ }^{45}$

Podemos extrair, também, do Censo 2010 os dados relativos à ocupação das pessoas que se declararam deficientes. É relevante destacar que desses dados não se pode extrair a ocupação das pessoas com deficiência severa. O levantamento se limitou a fazer o estudo em relação ao grande grupo: pessoas deficientes.

Tabela 6 - Deficientes por idade e ocupação

\begin{tabular}{lrrrr}
\hline & \multicolumn{1}{c}{ Total } & Ocupados & \multicolumn{1}{c}{$\begin{array}{c}\text { Não } \\
\text { ocupados }\end{array}$} & $\begin{array}{r}\text { Taxa de } \\
\text { Ocupação }\end{array}$ \\
\hline Mais de 65 anos & 9.537 .625 & 1.501 .590 & 8.036 .035 & $15,74 \%$ \\
15 a 64 anos & 32.609 .022 & 18.743 .537 & 13.865 .485 & $57,48 \%$ \\
00 a 14 anos & 1.926 .730 & 120.837 & 1.805 .893 & $6,27 \%$ \\
Total & 44.073 .377 & 20.365 .964 & 23.707 .413 & \\
\hline
\end{tabular}

Fonte: Censo $2010^{46}$. 
Tabela 7 - Não deficientes por idade e ocupação

\begin{tabular}{lrrrr}
\hline & \multicolumn{1}{c}{ Total } & \multicolumn{1}{c}{ Ocupados } & \multicolumn{1}{c}{$\begin{array}{c}\text { Não } \\
\text { ocupados }\end{array}$} & $\begin{array}{c}\text { Taxa de } \\
\text { Ocupação }\end{array}$ \\
\hline Mais de 65 anos & 4.545 .787 & 1.107 .490 & 3.438 .297 & $24,36 \%$ \\
15 a 64 anos & 98.063 .640 & 63.911 .688 & 34.151 .952 & $65,17 \%$ \\
00 a 14 anos & 15.237 .845 & 948.536 & 14.289 .309 & $6,22 \%$ \\
Total & 117.847 .272 & 65.967 .714 & 51.879 .558 & \\
\hline
\end{tabular}

Fonte: Censo $2010^{47}$.

Para efeito de estudo, dividimos a população por faixa de idades. A primeira com pessoas entre 0 a 14 anos, que normalmente deveriam estar afastadas do mercado de trabalho, sem ocupação remunerada. A faixa entre 15 e 64 anos, idade em que as pessoas geralmente estão no mercado de trabalho e uma faixa de pessoas acima de 65 anos, quando já estão se afastando desse mercado.

Na primeira faixa, apesar da proibição constitucional para o exercício de trabalho, o resultado foi bastante similar entre deficientes e não deficientes, $6,27 \%$ e 6,22\%, respectivamente. Assim, os deficientes até os catorze anos, segundo dados do Censo 2010, possuem atividade remunerada um pouco maior que os que se declaram não deficientes. É esse o único segmento etário, quando é proibida a atividade, no qual a ocupação é maior entre os deficientes, quando comparados aos não deficientes.

$\mathrm{Na}$ faixa principal, ligada à atividade laboral, entre os 15 e 64 anos, as divergências ocupacionais passam a existir de maneira mais flagrante. Entre os deficientes $57,48 \%$ estão ocupados, enquanto $65,17 \%$, entre os não deficientes, exercem atividade remunerada. Trata-se de uma relevante diferença de 7,69\%. $\mathrm{Na}$ faixa superior, das pessoas com idade superior aos 65 anos, a diferença aumenta. Entre os deficientes a taxa de ocupação é de 15,74 \%, entre os não deficientes é de $24,36 \%$, uma diferença de $8,62 \%$.

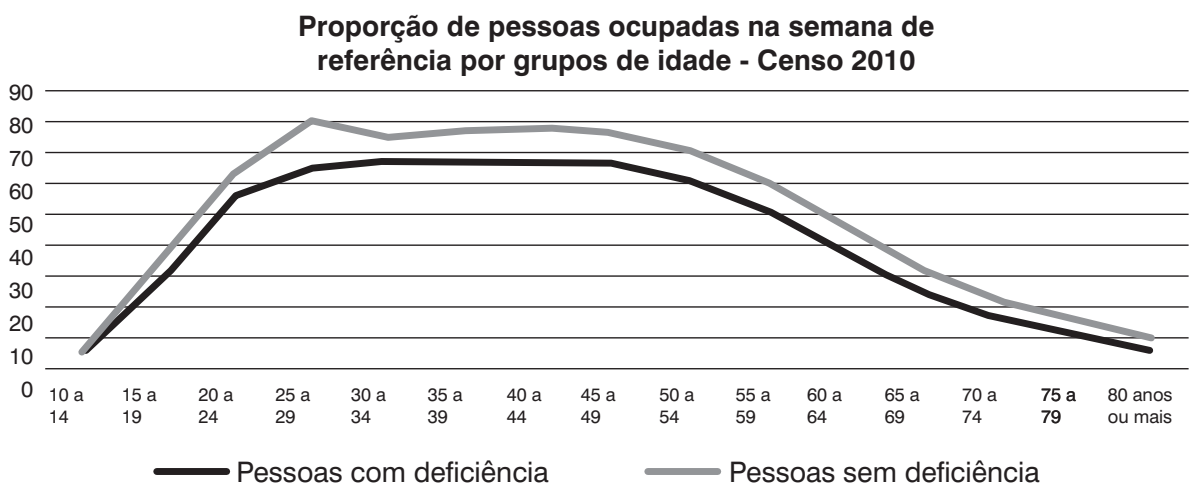


Observa-se, no gráfico, que a desigualdade é mantida ao longo de toda a sua extensão, havendo um aumento mais acentuado, de 15 pontos percentuais no grupo de 25 a 29 anos de idade. Essa divergência quase desaparece nas duas extremidades para o grupo de 10 a 14 anos, e para o de 80 anos ou mais de idade, levando-se em conta que o número de pessoas nesses grupos extremos é muito pequeno. ${ }^{48}$

O levantamento constatou, também, que a maioria das pessoas com deficiência ocupadas era empregada com carteira assinada (40,2\%). Número inferior em 9 pontos percentuais em relação à população sem nenhuma das deficiências investigadas $(49,2 \%)$. Na categoria empregador, há uma diferença de 0,3 ponto percentual entre a população sem $(2,1 \%)$ e com $(1,8 \%)$ deficiência.

Tabela 8 - Deficientes e não deficientes por atividade

\begin{tabular}{lcc}
\hline \multicolumn{1}{c}{ Tipo atividade } & Deficiente & Sem deficiência \\
\hline Não remunerado & $2,2 \%$ & $1,7 \%$ \\
Empregador & $1,8 \%$ & $2,1 \%$ \\
Militares e servidores & $5,9 \%$ & $5,5 \%$ \\
Empregado sem carteira & $22,5 \%$ & $20,6 \%$ \\
Trabalho por contra própria & $27,4 \%$ & $20,8 \%$ \\
Empregado com Carteira & $40,2 \%$ & $49,2 \%$ \\
\hline
\end{tabular}

Fonte: Censo $2010^{49}$.

Gráfico 2 - Ocupação dos deficientes por atividade em 2010

\section{Deficiente}

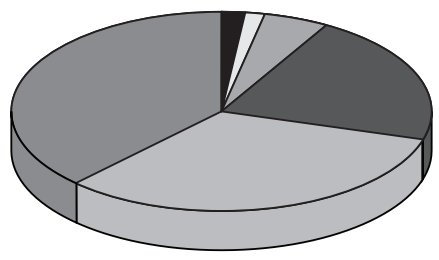

Não remunerado

Empregador

Militares e servidores

Empregado sem carteira

Trabalho por contra própria

Empregado com Carteira

Os percentuais de trabalhadores com deficiência classificados nas categorias por conta própria $(27,4 \%)$, sem carteira $(22,5 \%)$, militares e funcionários 
públicos estatutários $(5,9 \%)$ e não remunerados $(2,2 \%)$ são maiores do que na população sem deficiência $(20,8 \%, 20,6 \%$ e $5,5 \% ; 1,7 \%$, respectivamente). Interessante observar que, ressalvada a atividade como militares e servidores, onde há a reserva de vagas nos editais de concurso, quando há escolha por parte do empregador, o percentual de deficientes só surge mais elevado na ocupação não remunerada e na ocupação sem o devido registro.

O impacto das barreiras ainda existentes se reflete nos indicadores que medem a inclusão das pessoas com deficiência no mercado de trabalho. O Censo 2010, mostra que há uma diferença na proporção de pessoas ocupadas entre a população com e sem deficiência. Além disso, é demonstrado pela disposição dentro de cada categoria, que os deficientes estão distribuídos nas piores vagas do mercado de trabalho.

\section{DADOS DA RELAÇÃO ANUAL DE INFORMAÇÕES SOCIAIS (RAIS)}

Os dados encontrados na Relação Anual de Informações Sociais (RAIS) são diferentes dos encontrados no Censo. A RAIS apresenta um mapeamento do mercado formal, divulgados anualmente pelo Ministério do Trabalho e Previdência Social (MTPS). Desde o ano de 2007, passou a trazer dados relativos aos trabalhadores com deficiência e tem como base informações prestadas pelos empregadores. O Censo Demográfico de 2010, realizado pelo IBGE, apura no seu questionário amostral, as condições de trabalho daqueles com algum tipo de deficiência, segundo informações coletadas por meio de entrevistas e questionários.

É preciso conhecer os critérios utilizados, para que se tenha compreensão adequada dos resultados encontrados e de suas diferenças. No caso do Censo Demográfico, a deficiência ou limitação funcional é autodeclarada. $\mathrm{Na}$ RAIS, essa condição é fornecida pelo empregador, devendo ter por base atestados médicos que declarem a deficiência. Legislação específica define quem pode atestar e de que maneira as deficiências serão comprovadas. Compete ao Ministério do Trabalho e Previdência Social estabelecer a sistemática de fiscalização, a avaliação e o controle das empresas, assim como instituir os procedimentos e formulários necessários à contratação.

Uma das determinações é a necessidade do laudo médico, que pode ser emitido por médico do trabalho da empresa ou outro médico, que ateste a deficiência de acordo com as definições do Decreto $n^{0}$ 3.298/99 (artigos $3^{\mathrm{o}}$ e $\left.4^{\mathrm{O}}\right)^{50}$, com as alterações definidas pelo Decreto $\mathrm{n}^{\mathrm{o}} 5.296 / 2004 .{ }^{51}$

O laudo deverá especificar o tipo de deficiência, com o código correspondente da Classificação Internacional de Doenças (CID), e ter autorização expressa do empregado para tornar pública a sua condição. A CID é publicada pela Organização Mundial de Saúde (OMS) e fornece códigos relativos à classificação de doenças e de uma grande variedade de sinais, sintomas, aspectos anormais, queixas, circunstâncias sociais e causas externas para ferimentos 
ou doenças. A cada estado de saúde é atribuída uma categoria única, à qual corresponde um código, que contém até seis caracteres.

A CID é revista periodicamente e no momento está em vigor a sua décima edição, a CID-10. Dependendo da deficiência, a avaliação deverá ser feita por um especialista e os laudos devem ser recentes, emitidos há menos de um ano. Nos casos de pessoas com deficiência auditiva e visual é necessário apresentar os exames de audiometria e oftalmológico, respectivamente. Quanto à deficiência intelectual, é aceito o laudo elaborado por um psicólogo.

A audiometria deve comprovar a perda auditiva superior a 41 decibéis, nas frequências $500 \mathrm{~Hz}, 1.000 \mathrm{~Hz}, 2.000 \mathrm{~Hz}$, e $3.000 \mathrm{~Hz}$, e em ambos os ouvidos. O médico não deve considerar a média aritmética, e sim a perda em todas as frequências. $\mathrm{O}$ laudo oftalmológico deve comprovar a acuidade visual, não são as doenças do campo visual que atestam a deficiência, mas sim a somatória da perda visual nos dois olhos. Ainda assim, o médico deve levar em conta a acuidade com o uso da melhor correção: óculos ou lentes de contato. ${ }^{52}$

Desta forma, pode-se dizer que somente uma pequena parcela daqueles que se dizem deficientes no Censo é que atendem os critérios de deficiência para efeito da RAIS. Provavelmente, estão afastados desse critério todos aqueles que afirmam ter "alguma dificuldade", restando um universo de 15.750.969 deficientes, o que representa $8,26 \%$ da população.

Importante ressaltar, entretanto, que os dados do Censo 2010 não apontam a deficiência múltipla. Essa carência de informação permite que o mesmo deficiente possa ser contabilizado, por mais de uma vez. Assim é que a soma de todos os deficientes enumerados, por deficiência (61.368.845), é superior ao número total de deficientes (45.606.048).

Através de rápido cálculo, podemos inferir que 15.762 .797 (34,56\%) possui mais de um tipo de deficiência, tendo sido contabilizado mais de uma vez. Levando essa mesma proporção para os deficientes em situação mais grave (15.750.969), teríamos que 10.306 .969 da população brasileira tem deficiência grave. Número que representa 5,40\% de toda a população.

Da mesma forma, o Estado do Ceará, segundo dados do Censo 2010, possui um total de 2.340.329 deficientes, sendo que a soma dos deficientes, por tipo de deficiência, é de 3.206.983. Esses dados indicam que 37,03\% possuem mais de uma deficiência, tendo sido contabilizados mais de uma vez. Assim, levando essa proporção para o número de deficientes mais graves, temos que 528.266 moradores do Ceará possuem deficiência severa. Número que representa cerca de 6,25\% da população do Estado do Ceará. ${ }^{53}$

Feitos esses esclarecimentos, apresentamos o instrumento de verificação da ocupação das vagas de emprego por parte dos deficientes. O relatório da 
RAIS classifica os tipos de deficiência em: a) física; b) auditiva; c) visual; d) intelectual d) múltipla e f) reabilitado.

Reabilitado é aquele que passou por processo orientado a possibilitar que adquira, a partir da identificação de suas potencialidades, o nível suficiente de desenvolvimento profissional para reingresso no mercado de trabalho e participação na vida comunitária.$^{54}$ Essa condição é provada através de documento oficial, expedido através do Instituto Nacional do Seguro Social (INSS). Conceitua-se como deficiência múltipla a associação de duas ou mais deficiências, citadas.

Tabela 9 - Deficientes empregados no Brasil por tipo de deficiência

\begin{tabular}{ccccc}
\hline Tipo & 2012 & 2013 & Variação & Ocupação \\
\hline Física & 170.468 & 181.464 & 6,45 & $50,72 \%$ \\
Auditiva & 74.385 & 78.078 & 4,96 & $21,82 \%$ \\
Visual & 26.119 & 33.505 & 28,28 & $9,36 \%$ \\
Intelectual & 21.317 & 25.332 & 18,83 & $7,08 \%$ \\
Múltipla & 4.696 & 5.490 & 16,91 & $1,53 \%$ \\
Reabilitado & 33.311 & 33.928 & 1,85 & $9,48 \%$ \\
Totais & 330.296 & 357.797 & 8,33 & $100,00 \%$ \\
\hline
\end{tabular}

Fonte: RAIS 2012 e 2013.

Gráfico 3 - Deficientes empregados no Brasil por tipo de deficiência no ano de 2013.

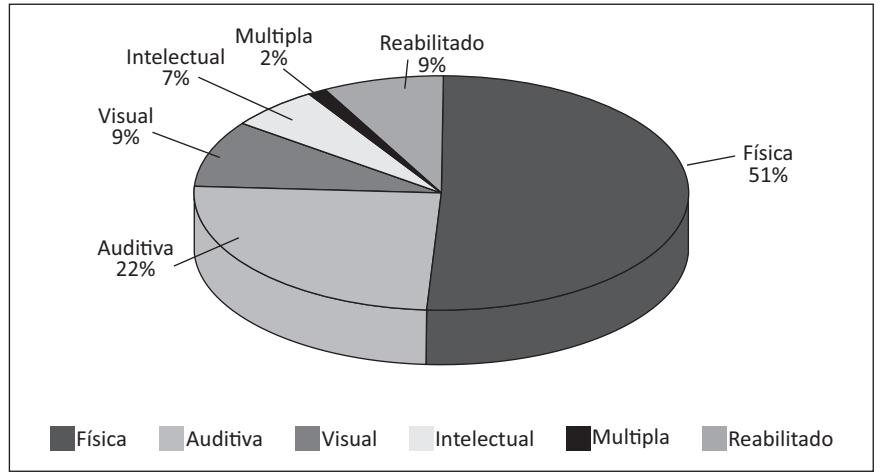


Tabela 10 - Deficientes empregados no Ceará por tipo de deficiência

\begin{tabular}{lrrrr}
\hline \multicolumn{1}{r}{ Tipo } & 2012 & \multicolumn{1}{r}{2013} & Variação & Ocupação \\
\hline Física & 7.645 & 8.346 & 9,17 & $62,43 \%$ \\
Auditiva & 2.182 & 2.370 & 8,62 & $17,73 \%$ \\
Visual & 976 & 1.227 & 25,72 & $9,18 \%$ \\
Intelectual & 229 & 263 & 14,85 & $1,97 \%$ \\
Múltipla & 98 & 112 & 14,29 & $0,84 \%$ \\
Reabilitado & 1.005 & 1.050 & 4,48 & $7,85 \%$ \\
Totais & 12.135 & 13.368 & 10,16 & $100,00 \%$ \\
\hline
\end{tabular}

Fonte: Rais 2012 e 2013.

Gráfico 4 - Deficientes empregados no Ceará por tipo de deficiência no ano de 2013

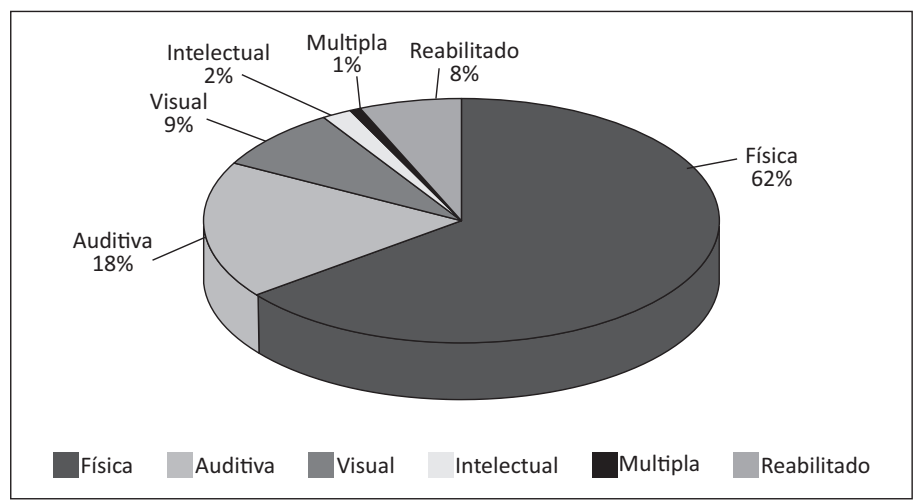

Em 2013, verificou-se no Brasil um aumento de 8,33\% no número de pessoas declaradas como deficientes (PCD) empregadas no país. O que representou um acréscimo de 27.501 vínculos, totalizando 357.797 vínculos declarados no ano. No Estado do Ceará, no mesmo período, tivemos um incremento de 10,16\%, maior que a média nacional, representando um acréscimo de 1.233 empregos formais, totalizando 13.368 vínculos.

A comparação da distribuição de vagas ocupadas no Brasil e no Estado do Ceará é bastante interessante. Á deficiência física no Ceará é destacadamente a de maior grau de empregabilidade. Representa $62,43 \%$ de todos os vínculos empregatícios, enquanto no Brasil esse percentual é de 50,72\%. A deficiência intelectual e auditiva, comparativamente, é desprestigiada no Ceará, representando apenas $2 \%$ e $18 \%$, enquanto no Brasil é de $7 \%$ e 22\%, respectivamente. 


\section{A ATUAÇÃO DO MINISTÉRIO DO TRABALHO E PREVIDÊNCIA SOCIAL}

Um dos projetos obrigatórios da auditoria fiscal do Ministério do Trabalho e Previdência Social é aquele que objetiva promover a inclusão de pessoas com deficiência e reabilitados no mercado de trabalho.

O termo inclusão, como já apresentado, segue a ideia geral de que o objetivo principal das ações da auditoria não é somente quantitativo. O objeto da ação fiscal nas empresas, com o fito de implementar a política pública governamental de inclusão dos deficientes, não se exaure apenas com o quantitativo de registros. Estende-se a uma análise qualitativa dos vínculos constituídos.

Tabela 11 - Atividade do Ministério do Trabalho

\begin{tabular}{lrr} 
& 2012 & \multicolumn{1}{c}{2013} \\
\hline Ações Fiscais & 538 & 577 \\
PCD & 1.594 & 2.359 \\
Aprendizes & & 104 \\
\hline
\end{tabular}

Fonte: SFITWEB

Devem ser observadas as especificidades das pessoas com deficiência e reabilitadas, verificando-se a adequação das atividades a serem exercidas em relação ao tipo de deficiência ou restrição apresentada. Além disso, é preciso verificar a existência do tratamento igualitário em relação aos demais empregados, evitando a discriminação na seleção, durante o contrato de trabalho e após a extinção do vínculo. Além disso, é preciso avaliar as condições de trabalho.

Entretanto, por limitações estruturais da auditoria, no Estado do Ceará, as ações fiscais são realizadas, quase exclusivamente, na modalidade indireta, abrangendo especificamente atributos diretamente relacionados ao registro dos empregados com deficiência-PCD.

Na modalidade indireta a empresa é chamada ao órgão local do Ministérios do Trabalho e Previdência Social, devendo comprovar que cumpre a cota determinada segundo os dispositivos legais. No ano de 2012 foram executadas 538 ações fiscais, tendo sido contratados durante a ação 1.594 pessoas com deficiência (PCD). O ano de 2013 teve resultados, ainda melhores, em 577 ações fiscais, foram contratados 2.359 pessoas com deficiência (PCD). Esses números são muito importantes pois ajudam a explicar por que o estado do Ceará é aquele onde há os melhores resultados quantitativos de inclusão no Brasil.

Além de ter como base as experiências dos anos anteriores, o projeto conta com o incremento de um sistema, que é capaz de relacionar um completo banco de empresas sujeitas à reserva legal de inclusão de pessoas com deficiência e reabilitadas do INSS. Através de uma simples consulta é capaz de se listar todas as empresas que estão aquém de suas cotas. 
Tabela 12 - Empresas e cotas preenchidas

\begin{tabular}{cccccccccc}
\hline $\begin{array}{c}\text { Porte da } \\
\text { empresa }\end{array}$ & $\begin{array}{c}\text { Número } \\
\text { de } \\
\text { empresas }\end{array}$ & $\begin{array}{c}\text { Empresas } \\
\text { inadim- } \\
\text { plentes }\end{array}$ & $\%$ & $\begin{array}{c}\text { Total } \\
\text { de } \\
\text { Cotas }\end{array}$ & $\begin{array}{c}\text { Cotas } \\
\text { não pre- } \\
\text { enchidas }\end{array}$ & $\%$ & $\begin{array}{c}\text { Total } \\
\text { empre- } \\
\text { gados }\end{array}$ & $\begin{array}{c}\text { PCD } \\
\text { Contra- } \\
\text { tados }\end{array}$ & $\%$ \\
\hline $100-200$ & 509 & 400 & 78,59 & 1.638 & 1.120 & 68,38 & 70.781 & 661 & 0,93 \\
$201-500$ & 342 & 252 & 73,68 & 3.337 & 1.693 & 50,73 & 108.390 & 1.890 & 1,74 \\
$501-1000$ & 198 & 169 & 85,35 & 5.541 & 3.593 & 64,84 & 140.029 & 2.393 & 1,71 \\
$>1000$ & 164 & 149 & 90,85 & 25.348 & 16.727 & 65,99 & 515.207 & 9.147 & 1,78 \\
Totais & 1.213 & 970 & 79,97 & 35.864 & 23.133 & 64,50 & 834.407 & 14.091 & \\
\hline
\end{tabular}

Fonte: IDEB, Dados de dezembro de 2015.

Os dados da tabela acima foram extraídos desse sistema (IDEB). Com isso, pretende-se alcançar o maior número possível de empresas e de PCD a serem inseridas no mercado de trabalho. Por intermédio dessa tabela notamos que o máximo esforço será obtido quando no Estado do Ceará tivermos incluído um total de 35.864 empregados. Segundo esses dados, temos um total de 12.731 cotas preenchidas.

Segundo o projeto, a área de abrangência engloba Fortaleza e Região Metropolitana, como também as regiões do Cariri e Sobral, podendo ser incluídos outros municípios, observada a demanda local, bem como os recursos materiais e orçamentários para deslocamento dos Auditores Fiscais do Trabalho, alocados no projeto. Não serão inseridas neste projeto empresas com menos de 100 empregados, pois não foram contempladas no Art. 93, da Lei no 8.213/91.

$\mathrm{Na}$ Superintendência do Trabalho e Emprego no Ceará (SRTE/CE), não há previsão no projeto de qualquer análise especial em relação à Segurança e Saúde do trabalhador deficiente, onde seria avaliada a correta adequação das atividades às especificidades das pessoas com deficiência ou reabilitadas, bem como eliminaria eventuais ações que consubstanciem assédio moral contra estes trabalhadores.

Não existe, também, a inclusão de um auditor médico para a análise de laudos médicos caracterizadores de pessoas com deficiência e analise a adequação de funções às deficiências e restrições. A inclusão de pessoas com deficiência no Mercado de Trabalho está dentro dos compromissos nacionais do Ministério do Trabalho e Previdência Social (MTPS).

A inclusão de empregados com deficiência/reabilitados decorre da verificação fática que eles são discriminados no acesso ao mercado de trabalho e consagra os dispositivos constitucionais de promoção da dignidade da pessoa humana, em sua vertente de trabalhador com deficiência/reabilitado, de combate à discriminação e o assédio moral contra os trabalhadores deste segmento, e de respeito ao valor social do trabalho. 
Por se tratar de uma atividade com uma grande relutância de cumprimento por parte das empresas, com natureza de política pública e ação afirmativa. É necessário para a efetividade dos resultados obtidos, além da fiscalização propriamente dita, uma série de outras ações, de forma a promover a igualdade de tratamento, não só pela contratação, mas também no curso da relação empregatícia.

Ressalte-se também que as alterações advindas da Lei 12.470/2011, repetidas no Estatuto da Pessoa com Deficiência, promoveram radicais modificações na inclusão no mundo do trabalho. Entre as principais alterações, podemos citar o novo conceito de deficiência que vai além da ótica médica, incorporando as barreiras atitudinais, que dificultam a inclusão no mercado de trabalho.

Ressalte-se também que no texto alterado, a inclusão da expressão "mental”, sem menção a qualquer graduação, certamente estimulará a tentativa de incluir na reserva legal certos transtornos mentais que, por si só, até então não caracterizavam deficiência. A extrema abertura do conceito ensejará a necessidade de atenção redobrada e, na medida do possível, a uniformização de decisões em situações similares.

Como efeito positivo, as alterações legais permitirão que certas categorias anteriormente não abrangidas na lei, mas que são vítimas de discriminação, como visão monocular, gagueira grave, deformidades faciais graves possam vir a ser consideradas como deficiência.

Uma das maiores reclamações dos empresários, ao argumentar a dificuldade de contratar pessoas com deficiência aptas ao trabalho, era que muitos se recusavam a serem registrados, em face do medo de perder definitivamente a percepção do Benefício de Prestação Continuada (BPC). A nova legislação deixa bastante claro que o BPC será meramente suspenso enquanto persistir o vínculo empregatício. Para a retomada do benefício, sequer será necessária a realização de nova perícia, a qual só será exigida por ocasião do lapso temporal previsto para a reavaliação de cada beneficiário (02 anos).

Essa nova possibilidade estimulará a inclusão de pessoas com deficiência por meio da aprendizagem, a qual independe de idade para a pessoa com deficiência, uma vez que além de não perder o BPC, passará a recebê-lo em conjunto com a remuneração da aprendizagem. A aprendizagem parece ser um dos melhores caminhos para eliminar certos preconceitos por parte dos gestores das empresas, uma vez que há a oportunidade de conhecer e avaliar os aprendizes com deficiência durante a parte prática do processo de aprendizagem, objetivando sempre a sua contratação de modo definitivo.

O Estatuto da Pessoa Deficiente prevê, ainda, o auxílio-inclusão que deverá ser pago ao deficiente, a partir de sua admissão. Esse benefício, que ainda depende de regulamentação dos seus critérios e valor do auxílio, visa a amparar o custeio das despesas do deficiente que trabalha no mercado formal. 


\section{CONSIDERAÇÕES FINAIS}

O caminho traçado pelos portadores de deficiência ao longo dos anos é marcado pela superação. A história da construção dos direitos humanos da pessoa com deficiência é compreendida, marcadamente, de fases. Inicialmente, há o tempo da intolerância total, no qual a deficiência simbolizava impureza, pecado ou castigo divino. Na melhor das situações, essa intolerância era marcada pela invisibilidade das pessoas com deficiência. A seguir podemos caracterizar outra fase, que foi orientada por uma ótica assistencialista, em que a deficiência era uma doença a ser curada.

A fase atual é orientada pelo paradigma dos direitos humanos, de onde emerge os direitos à inclusão social, com ênfase na relação da pessoa com deficiência e do meio em que se ela se insere. A ideia é que é preciso eliminar obstáculos e barreiras superáveis, sejam elas culturais, físicas ou sociais que impeçam o pleno exercício dos direitos humanos por parte das pessoas com deficiência. Todo ser humano tem direito de desfrutar das condições necessárias para o desenvolvimento de suas potencialidades, com autonomia e participação.

A Convenção sobre os Direitos das Pessoas com Deficiência foi inspirada por essa ideia renovadora. O seu texto compreende que a pessoa com deficiência é aquela que têm impedimentos de longo prazo de natureza física, mental, intelectual ou sensorial, os quais, em interação com diversas barreiras, podem obstruir sua participação plena e efetiva na sociedade em igualdade de condições com as demais pessoas.

Além de um novo conceito para os indivíduos deficientes, a Convenção apontou para a necessidade de promover, proteger e assegurar o pleno exercício dos direitos humanos destes. A tarefa a ser desenvolvida exigiu dos Estados-partes políticas públicas que promovessem a inclusão social das pessoas com deficiência, através de medidas legislativas e administrativas.

A legislação nacional tem cumprido com o seu compromisso, sendo considerada uma das mais avançadas no mundo sobre essa temática. Desde a Constituição Federal de 1988 até a Convenção Internacional sobre os Direitos das Pessoas com Deficiência, ratificada pelo país em 2008, foi definida uma gama variada de temas e direitos que são objeto de garantias legais. Particularmente no campo do acesso ao trabalho, destaca-se a previsão de cotas a serem preenchidas nas empresas privadas e a reserva de vagas para pessoas com deficiência em concursos públicos.

A Lei Brasileira de Inclusão da Pessoa com Deficiência, definida como $O$ Estatuto da Pessoa com Deficiência, vem dar prosseguimento aos esforços brasileiros pela inclusão social destes indivíduos. A tônica do seu texto é a criação de condições trabalho, de forma competitiva, em igualdade de oportunidades com as demais pessoas, e de forma a serem atendidas as regras de acessibilidade, $o$ fornecimento de recursos de tecnologia assistiva e adaptação razoável no ambiente do trabalho. Certamente, apesar de sua importância, a legislação não teve ainda o poder de transformar a sociedade. 
As leis que exigem complemento de cotas de deficientes para empresas privadas e aquela que a reserva de vagas para pessoas com deficiência já estão completando 25 (vinte e cinco) anos. Essas leis apresentam requisitos meramente quantitativos, mesmo assim, apesar de todo o esforço, são a todo momento olvidadas pelos entes privados e estatais. O processo de inclusão social é lento.

Em termos quantitativos, os números obtidos comprovam que ainda há uma clara desproporção entre pessoas ocupadas e desocupadas, em relação a existência ou não de deficiência. Além disso, mesmo dentro do grupo de pessoas ocupadas, há uma clara tendência para que as com deficiência sejam admitidas em relações de trabalho com traços de precariedade. Entretanto, é possível verificar que ao longo dos últimos anos a inclusão de deficientes tem tido curva ascendente.

A verdadeira inclusão, entretanto, não pode ser meramente quantitativa. É preciso verificar se as barreiras ou dificuldades de acesso à igualdade de oportunidades estão sendo combatidas.

Nesse ponto, há uma grande dificuldade. Para isso seria preciso realizar a verificação in loco de quais as atividades e como estas são desempenhadas pelo portador de deficiência. Infelizmente, a realidade do Ministério do Trabalho e Previdência Social não permite esse tipo de fiscalização, que exige tempo e especialidade, limitando-se quase sempre à mera verificação das empresas, para analisar se estão cumprindo ou não as cotas de empregados com deficiência.

A medida que a população brasileira envelhece, o número de pessoas deficientes tende a crescer. É importante que as políticas públicas avancem e que nossa sociedade esteja preparada para receber, quem sabe, a maioria de seus membros.

\section{REFERÊNCIAS}

ALESSIO, Rosemeri. Responsabilidade Social das Empresas no Brasil: reprodução de postura ou novos rumos? Porto Alegre: EDIPUCRS, 2004.

AMIRALIAN, Maria L. T. Conceituando deficiência. Revista de Saúde Pública, São Paulo, v. 34, n. 1, p. 97-103, 2000.

BRASIL. Constituição da República Federal do Brasil de 1988. Disponível em: $<$ https://www.planalto.gov.br/ccivil_03/Constituicao/ConstituicaoCompilado. htm >. Acesso em: 1 mar. 2016.

. Decreto $\mathrm{n}^{\circ} 3.298$, de 20 de dezembro de 1999. Regulamenta a Lei no 7.853, de 24 de outubro de 1989, dispõe sobre a Política Nacional para a Integração da Pessoa Portadora de Deficiência, consolida as normas de proteção, e dá outras providências. Presidência da República. Disponível em: <http:// www.planalto.gov.br/ccivil_03/decreto/D3298.htm >. Acesso em: 14 fev. 2016.

. Decreto $\mathrm{n}^{\mathrm{O}} 3.956$, de 08 de outubro de 2001. Promulga a Convenção Interamericana para a Eliminação de Todas as Formas de Discriminação contra 
as Pessoas Portadoras de Deficiência. Presidência da República. Disponível em: <http://www.planalto.gov.br/ccivil_03/decreto/2001/D3956.htm>. Acesso em: 14 fev. 2016.

. Decreto Legislativo $\mathbf{n}^{\mathbf{0}}$ 186. Aprova o texto da Convenção sobre os Direitos das Pessoas com Deficiência e de seu Protocolo Facultativo, assinados em Nova Iorque, em 30 de março de 2007. Presidência da República. Disponível em: <http:/www.planalto.gov.br/ccivil 03/constituicao/Congresso/DLG/ DLG-186-2008.htm>. Acesso em: 14 fev. 2016.

. Decreto n. ${ }^{\circ}$ 6.949, de 25 de agosto de 2009. Promulga a Convenção Internacional sobre os Direitos das Pessoas com Deficiência e seu Protocolo Facultativo, assinados em Nova York, em 30 de março de 2007. Presidência da República. Disponível em: <http://www.planalto.gov.br/ccivil_03/_Ato20072010/2009/Decreto/D6949.htm >. Acesso em: 14 fev. 2016.

. Decreto no 129, de 22 de maio de 1991. Promulga a Convenção no ${ }^{\circ} 159$, da Organização Internacional do Trabalho - OIT, sobre Reabilitação Profissional e Emprego de Pessoas Deficientes. Presidência da República. Disponível em: <http://www.planalto.gov.br/ccivil_03/decreto/1990-1994/D0129.htm>. Acesso em: 16 mar. 2016.

. Decreto-Lei $\mathrm{n}^{\circ} 5.452$, de $1^{\circ}$ de maio de 1943. Aprova a Consolidação das Leis do Trabalho. Presidência da República. Disponível em: <http://www. planalto.gov.br/ccivil_03/decreto-lei/Del5452compilado.htm $>$. Acesso em: 1 mar. 2016.

. Emenda Constitucional n. ${ }^{\circ} 45$, de 31 de dezembro de 2004. Altera dispositivos dos arts. 50 , 36, 52, 92, 93, 95, 98, 99, 102, 103, 104, 105, 107, 109, 111, 112, 114, 115, 125, 126, 127, 128, 129, 134 e 168 da Constituição Federal, e acrescenta os arts. 103-A, 103B, 111-A e 130-A, e dá outras providências. Presidência da República. Disponível em: <http://www.planalto.gov. br/ccivil_03/Constituicao/Emendas/Emc/emc45.htm>. Acesso em: 14 fev. 2016.

. Lei ${ }^{\circ} 11.180$, de 23 de setembro de 2005. Institui o Projeto Escola de

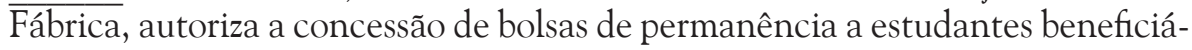
rios do Programa Universidade para Todos - PROUNI, institui o Programa de Educação Tutorial - PET, altera a Lei no 5.537 , de 21 de novembro de 1968, e a Consolidação das Leis do Trabalho - CLT, aprovada pelo Decreto-Lei no 5.452, de $1^{\circ}$ de maio de 1943, e dá outras providências. Presidência da República. Disponível em: < http://www.planalto.gov.br/ccivil_03/_Ato2004-2006/2005/ Lei/L11180.htm>. Acesso em: 14 fev. 2016.

. Lei n ${ }^{\circ} 12.470$, de 31 de agosto de 2011. Acrescenta o art. 21-A à Lei $\overline{\mathrm{n}^{\circ} 8.742}$, de 7 de dezembro de 1993 - Lei Orgânica de Assistência Social, para alterar regras do benefício de prestação continuada da pessoa com deficiência. Presidência da República. Disponível em: <http://www.planalto.gov.br/CCIVIL_03/_Ato2011-2014/2011/Lei/L12470.htm >. Acesso em: 14 fev. 2016. 
. Lei $\mathrm{n}^{\mathrm{o}}$ 13.146, de 6 de julho de 2015. Institui a Lei Brasileira de Inclusão da Pessoa com Deficiência (Estatuto da Pessoa com Deficiência). Presidência da República. Disponível em: <http://www.planalto.gov.br/ CCIVIL_03/_Ato2015-2018/2015/Lei/L13146.htm>. Acesso em: 29 fev. 2016.

. Lei $\mathrm{n}^{\mathrm{O}} 7.853$, de 24 de outubro de 1989. Dispõe sobre o apoio às pessoas portadoras de deficiência, sua integração social, sobre a Coordenadoria Nacional para Integração da Pessoa Portadora de Deficiência - Corde, institui a tutela jurisdicional de interesses coletivos ou difusos dessas pessoas, disciplina a atuação do Ministério Público, define crimes, e dá outras providências. Presidência da República. Disponível em: <http://www.planalto.gov.br/ccivil_03/Leis/L7853. htm >. Acesso em: 14 fev. 2016.

. Lei n ${ }^{\circ} 8.112$, de 11 de dezembro de 1990. Dispõe sobre o regime jurídico dos servidores públicos civis da União, das autarquias e das fundações públicas federais. Presidência da República. Disponível em: <http://www.planalto.gov. br/ccivil_03/LEIS/L8112cons.htm>. Acesso em: 1 mar. 2016.

. Lei no 8.213, de 24 de julho de 1991. Dispõe sobre os Planos de Benefícios da Previdência Social e dá outras providências. Presidência da República. Disponível em: < http://www.planalto.gov.br/ccivil_03/LEIS/L8213cons.htm>. Acesso em: 14 fev. 2016.

. Lei $\mathrm{n}^{\mathrm{o}}$ 8.666, de 21 de junho de 1993. Regulamenta o art. 37, inciso

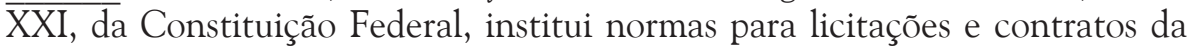
Administração Pública e dá outras providências. Presidência da República. Disponível em: <http://www.planalto.gov.br/ccivil_03/Leis/L8666cons.htm>. Acesso em: 14 fev. 2016.

. Lei Complementar $n^{\circ} 142$, de 08 de maio de 2013. Regulamenta o $\S$ 10 do art. 201 da Constituição Federal, no tocante à aposentadoria da pessoa com deficiência segurada do Regime Geral de Previdência Social - RGPS. Presidência da República. Disponível em <http://www.planalto.gov.br/ccivil_03/ LEIS/LCP/Lcp142.htm>. Acesso em: 1 mar. 2016

. Projeto de Lei n ${ }^{0} 7.699$, de 21 de dezembro de 2006. Institui o Estatuto do Portador de Deficiência e dá outras providências. Câmara dos Deputados. Disponível em: < http://www.camara.gov.br/proposicoesWeb/fichadetramitac ao? idProposicao=33940>. Acesso em: 14 fev. 2016.

CENSO DEMOGRÁFICO 2010. Características da população e dos domicílios: resultados do universo. Rio de Janeiro: IBGE, 2011. Disponível em: <http:// censo2010.ibge.gov.br/>. Acesso em: 29 fev. 2016.

. Características gerais da população, religião e pessoas com deficiência. Rio de Janeiro: IBGE, 2012. Disponível em: < http://censo2010.ibge.gov.br/>. Acesso em: 29 fev. 2016. 
COUTINHO, R. B. G.; MACEDO-SOARES, T. D. L. V. A. Gestão Estratégica com Responsabilidade Social: Arcabouço Analítico para auxiliar sua implementação em empresas no Brasil. Revista de Administração Contemporânea, Rio de Janeiro, v.6, n. 3, p. 75-96 set./dez. 2002

FERNANDES, Lorena. Breve histórico da deficiência e seus paradigmas. Breve histórico da deficiência e seus paradigmas. Revista do Núcleo de Estudos e Pesquisas Interdisciplinares em Musicoterapia, Curitiba v. 2, p.132-144. 2011. Disponível em: <www.fap.pr.gov.br>. Acesso em: 14 fev. 2016.

FIGUEIRA, Emilio. Caminhando em silêncio: uma introdução à trajetória das pessoas com deficiência na História do Brasil. São Paulo: Giz Editorial, 2008.

HÉBER-SUFFRIN, Pierre. O “Zaratustra” de Nietsche. Rio de Janeiro: Jorge Zahar, 1991.

INSTITUTO BRASILEIRO GEOGRAFIA E ESTATÍSTICA - IBGE. Censo 1991. Disponível em: < http://www.ibge.gov.br/home/estatistica/populacao/ censodem/default_censo

1991.shtm>. Acesso em 1 mar. 2016.

.. Censo 2000: dados preliminares. Rio de Janeiro: IBGE, 2000. Disponível em: <www.ibge.gov.br>. Acesso em: 29 fev. 2016.

MAZZOTTA, Marcos J. Educação especial no Brasil: histórias e políticas públicas. São Paulo: Cortez, 1995.

. Trabalho docente e formação de professores de educação especial. São Paulo: EPU, 1993.

MEDEIROS, Marcelo; DINIZ, Débora. A nova maneira de se entender a deficiência e envelhecimento. Brasília: IPEA, 2004.

MELO NETO, F. P. de; FROES, C. Responsabilidade social e cidadania empresarial: a administração do terceiro setor. Rio de Janeiro: Qualitymark, 1999.

MINTZBERG, Henry. Power in and Around Organizations. Englewood Cliffs: Prentice-Hall, 1983.

ORCHIS, Marcelo A. et al. Responsabilidade social das empresas: a contribuição das universidades. São Paulo: Petrópolis, 2002.

ORGANIZAÇÃODAS NAÇÕES UNIDAS (ONU). Convenção Internacional sobre os Direitos das Pessoas com Deficiência. Disponível em: <http://www. pessoacomdeficiencia.gov.br/app/sites/default/files/publicacoes/convencaopessoascomdeficiencia.pdf >. Acesso em: $21 \mathrm{fev} .2016$.

. Declaração dos direitos das pessoas deficientes. Disponível em: < portal.

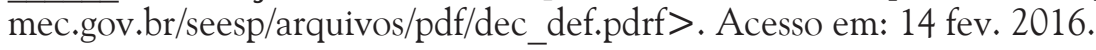

. Declaração Universal dos Direitos Humanos. Disponível em: <http:// www.dudh.org.br/declaracao/>. Acesso em: 14 fev. 2016. 
. Declaração de Direitos do Deficiente Mental. Disponível em: <http://www.direitoshumanos.usp.br/index.php/Direito-dos-Portadores-de-Defici\%C3\%AAncia/declaracao-de-direitos-do-deficiente-mental.html>. Acesso em: 1 mar. 2016.

PIOVESAN, Flávia. Direitos Humanos e os Direito Constitucional Internacional. 15. ed. São Paulo: Saraiva, 2015.

RIZZI, Fernanda Basaglia. Balanço Social e Ação de Responsabilidade Social das empresas. In: PRÊMIO ETHOS VALOR. Responsabilidade social das Empresas: a contribuição das universidades. São Paulo: Peirópolis, 2002. p. 173-194.

SILVA, Alexandre Antonio Bruno da. Nietzsche: direito e justiça. Rio de Janeiro: Lumen Juris, 2015.

SILVA, Otto Marques. A Epopeia Ignorada: a pessoa deficiente na história do mundo de ontem e de hoje. In: CARMO, Apolônio Abadio do. Deficiência Física: A realidade brasileira cria, recupera e discrimina. Brasília: MEC/Secretaria dos Desportos, 1991.

SISTEMA DE INDÍCIOS DE DÉBITO - IDEB. Secretaria da Inspeção do Trabalho - SIT. Departamento de Fiscalização do Trabalho. Disponível em: <http://fgts/IDEB/ConsultarQuatidadePCD.asp>. Acesso em: 10 mar 2016.

SISTEMA DA INSPEÇÃO FEDERAL DO TRABALHO - SFITWEB. Secretaria da Inspeção do Trabalho - SIT. Departamento de Fiscalização do Trabalho. Disponível em: <https://sfitweb.mte.gov.br>Acesso em: 10 mar 2016.

1 A expressão "epopeia ignorada" serve de título para a obra de Otto Marques da Silva que é leitura básica para conhecer a luta pela inclusão dos deficientes. SILVA, Otto Marques da. A epopeia ignorada: a pessoa deficiente na história do mundo de ontem e de hoje. São Paulo: CEDAS, 1986.

2 E, passando Jesus, viu um homem cego de nascença. E os seus discípulos lhe perguntaram, dizendo: Rabi, quem pecou, este ou seus pais, para que nascesse cego? Jesus respondeu: Nem ele pecou nem seus pais; mas foi assim para que se manifestem nele as obras de Deus. João 9:1-3.

3 FERNANDES, Lorena. Breve histórico da deficiência e seus paradigmas. Breve histórico da deficiência e seus paradigmas. Revista do Núcleo de Estudos e Pesquisas Interdisciplinares em Musicoterapia, Curitiba v. 2, p. 132 - 144. 2011. Disponível em: <http:/www.fap.pr.gov.br/arquivos/File/extensao/Arquivos2011/NEPIM/NEP

IM_Volume_02/Art08_NEPIM_Vol02_BreveHistoricoDeficiencia.pdf >. Acesso em: 14 fev. 2016.

4 HÉBER-SUFFRIN, Pierre. O “Zaratustra” de Nietsche. Rio de Janeiro: Jorge Zahar, 1991. p.64.

5 AMIRALIAN, Maria L. T. Conceituando deficiência. Revista de saúde pública, São Paulo, v. 34, n. 1, p. 97-103, 2000.

6 SILVA, Alexandre Antonio Bruno da. Nietzsche: direito e justiça. Rio de Janeiro: Lumen Juris, 2015. p.193.

7 MEDEIROS, M; DINIZ, D. A nova maneira de se entender a deficiência e envelhecimento. Brasília: IPEA, 2004.

8 ORGANIZAÇÃO DAS NAÇÕES UNIDAS (ONU). Declaração de Direitos do Deficiente Mental. Disponível em: <http://www.direitoshumanos.usp.br/index.php/Direito-dos-Portadores-de-Defici\%C3\%AAncia/declaracao-de-direitos-do-deficiente-mental.html>. Acesso em: 1 mar. 2016.

9 Se até aqui a pessoa com deficiência caminhou em silêncio, excluída ou segregada em entidades, a partir de 1981 - Ano Internacional da Pessoa Deficiente -, tomando consciência de si, passou a se organizar politicamente. E, como consequência, a ser notada na sociedade, atingindo significativas conquistas em pouco mais de 25 anos de militância (FIGUEIRA, 2008, p. 115). 
10 ORGANIZAÇÃO DAS NAÇÕES UNIDAS (ONU). Declaração dos direitos das pessoas deficientes. Disponível em: <http://portal.mec.gov.br/seesp/arquivos/pdf/dec_def.pdf>. Acesso em: 28 set. 2010.

11 BRASIL. Decreto ${ }^{\circ} 129$, de 22 de maio de 1991. Promulga a Convenção ${ }^{\circ}{ }^{159}$, da Organização Internacional do Trabalho - OIT, sobre Reabilitação Profissional e Emprego de Pessoas Deficientes. Presidência da República. Disponível em: <http://www.planalto.gov.br/ccivil_03/decreto/1990-1994/ D0129.htm>. Acesso em: 16 mar. 2016.

12 BRASIL. Decreto n ${ }^{\circ} 3.956$, de 08 de outubro de 2001. Promulga a Convenção Interamericana para a Eliminação de Todas as Formas de Discriminação contra as Pessoas Portadoras de Deficiência. Presidência da República Disponível em: < http://www.planalto.gov.br/ccivil_03/decreto/2001/d3956.htm>. Acesso em: 14 fev. 2016.

13 BRASIL. Decreto Legislativo $\mathbf{n}^{\circ}$ 186. Aprova o texto da Convenção sobre os Direitos das Pessoas com Deficiência e de seu Protocolo Facultativo, assinados em Nova Iorque, em 30 de março de 2007. Presidência da República. Disponível em: <http://www.planalto.gov.br/ccivil_03/constituicao/Congresso/ DLG/DLG-186-2008.htm>. Acesso em: 14 fev. 2016.

14 BRASIL. Decreto Legislativo $\mathbf{n}^{\circ}$ 186. Aprova o texto da Convenção sobre os Direitos das Pessoas com Deficiência e de seu Protocolo Facultativo, assinados em Nova Iorque, em 30 de março de 2007. Presidência da República. Disponível em: <http://www.planalto.gov.br/ccivil_03/constituicao/Congresso/ DLG/DLG-186-2008.htm>. Acesso em: 14 fev. 2016.

15 A Emenda Constitucional n..$^{\circ} 45$, de 31 de dezembro de 2004, acrescentou o parágrafo terceiro ao artigo quinto, cuja redação trata dos tratados e convenções sobre direitos humanos: "§ $3^{\circ}$ Os tratados e convenções internacionais sobre direitos humanos que forem aprovados, em cada Casa do Congresso Nacional, em dois turnos, por três quintos dos votos dos respectivos membros, serão equivalentes às emendas constitucionais". (BRASIL, 2010).

16 BRASIL. Decreto n ${ }^{\circ}$ 6.949, de 25 de agosto de 2009. Promulga a Convenção Internacional sobre os Direitos das Pessoas com Deficiência e seu Protocolo Facultativo, assinados em Nova York, em 30 de março de 2007. . Presidência da República. Disponível em: < http://www.planalto.gov.br/ccivil_03/_ato20072010/2009/decreto/d6949.htm>.

17 PIOVESAN, Flávia. Direitos Humanos e o Direito Constitucional Internacional. 15. ed. São Paulo: Saraiva, 2015. p. 303.

18 Ibid., p. 302.

19 Proibição de qualquer discriminação no tocante a salário e critérios de admissão do trabalhador portador de deficiência - art. $7^{\circ}, \mathrm{XXXI}$; A lei reservará percentual dos cargos e empregos públicos para as pessoas portadoras de deficiência e definirá os critérios de sua admissão - art. 37, VIII; A habilitação e reabilitação das pessoas portadoras de deficiência e a promoção de sua integração à vida comunitária por meio da assistência social - art. 203, IV; Criação de programas de prevenção e atendimento especializado para os portadores de deficiência física, sensorial ou mental, bem como de integração social do adolescente portador de deficiência, mediante o treinamento para o trabalho e a convivência, e a facilitação do acesso aos bens e serviços coletivos, com a eliminação de preconceitos e obstáculos arquitetônicos - art. $227, \S 1^{\circ}$, II; Construção dos logradouros e dos edifícios de uso público e de fabricação de veículos de transporte coletivo, a fim de garantir acesso adequado às pessoas portadoras de deficiência - art. 227, § $2^{\circ}$. BRASIL. Constituição da República Federal do Brasil de 1988. Disponível em: <https:/www.planalto.gov.br/ ccivil_03/Constituicao/ConstituicaoCompilado.htm>. Acesso em: 1 mar. 2016.

20 BRASIL. Lei no 8.112, de 11 de dezembro de 1990. Dispõe sobre o regime jurídico dos servidores públicos civis da União, das autarquias e das fundações públicas federais. Presidência da República. Disponível em: <http://www.planalto.gov.br/ccivil_03/LEIS/L8112cons.htm>. Acesso em: 1 mar. 2016.

21 BRASIL. Decreto n 3.298 , de 20 de dezembro de 1999. Regulamenta a Lei no 7.853, de 24 de outubro de 1989, dispõe sobre a Política Nacional para a Integração da Pessoa Portadora de Deficiência, consolida as normas de proteção, e dá outras providências. Presidência da República. Disponível em: <http:// www.planalto.gov.br/ccivil_03/decreto/D3298.htm>. Acesso em: 14 fev. 2016.

22 BRASIL. Lei no 8.213, de $2 \overline{4}$ de julho de 1991. Dispõe sobre os Planos de Benefícios da Previdência Social e dá outras providências. Presidência da República. Disponível em: <http://www.planalto.gov.br/ ccivil_03/LEIS/L8213cons.htm>. Acesso em: 14 fev. 2016.

23 Art. 93, Lei no 8.213/91. BRASIL. Lei 8.213, de 24 de julho de 1991. Dispõe sobre os Planos de Benefícios da Previdência Social e dá outras providências. Presidência da República. Disponível em: <http://www. planalto.gov.br/ccivil_03/LEIS/L8213cons.htm>. Acesso em: 14 fev. 2016. 
24 BRASIL. Lei n ${ }^{\circ} 7.853$, de 24 de outubro de 1989. Dispõe sobre o apoio às pessoas portadoras de deficiência, sua integração social, sobre a Coordenadoria Nacional para Integração da Pessoa Portadora de Deficiência - Corde, institui a tutela jurisdicional de interesses coletivos ou difusos dessas pessoas, disciplina a atuação do Ministério Público, define crimes, e dá outras providências. Presidência da República. Disponível em: <http://www.planalto.gov.br/ccivil 03/Leis/L7853.htm>. Acesso em: 14 fev. 2016.

25 BRASIL. Decreto-Lei $\mathbf{n}^{\circ} \mathbf{5 . 4 5 2}$, de $1^{\circ}$ de maio de 1943. Aprova a Consolidação das Leis do Trabalho. Presidência da República. Disponível em: < http://www.planalto.gov.br/ccivil_03/decreto-lei/Del5452compilado.htm $\geq$. Acesso em: 1 mar. 2016.

26 Nos demais segmentos da população, o limite é de 24 anos. O número de aprendizes deficientes era considerado para efeito de cálculo de cumprimento de cota de vagas, necessariamente preenchidas por deficientes. Essa consideração para o cumprimento de cotas foi afastada pelo Estatuto da Pessoa com Deficiência, não sendo mais contabilizado.

27 BRASIL. Lei Complementar $n^{\circ} 142$, de 08 de maio de 2013. Regulamenta o $\S 1$ o do art. 201 da Constituição Federal, no tocante à aposentadoria da pessoa com deficiência segurada do Regime Geral de Previdência Social - RGPS. Presidência da República. Disponível em: <http://www.planalto.gov.br/ ccivil_03/LEIS/LCP/Lcp142.htm>. Acesso em: 1 mar. 2016.

28 BRASIL. Lei no 13.146, de 6 de julho de 2015. Institui a Lei Brasileira de Inclusão da Pessoa com Deficiência (Estatuto da Pessoa com Deficiência). Presidência da República. Disponível em: <http://www. planalto.gov.br/CCIVIL_03/_Ato2015-2018/2015/Lei/L13146.htm Z. Acesso em: 29 fev. 2016.

29 Idem.

30 Art. 20 da Lei no 8.742, de 7 de dezembro de 1993, Estatuto da Pessoa com Deficiência.

31 BRASIL. Projeto de Lei $n^{0}$ 7.699/06, de 21 de dezembro de 2006. Institui o Estatuto do Portador de Deficiência e dá outras providências. Câmara dos Deputados. Disponível em: <http://www.camara.gov. br/proposicoesWeb/fichadetramitacao?idProposicao=33940 > . Acesso em: 14 de fev. 2016

32 Idem.

33 SISTEMA DE INDÍCIOS DE DÉBITO (IDEB). Secretaria da Inspeção do Trabalho - SIT. Departamento de Fiscalização do Trabalho. Disponível em: < http://fgts/IDEB/ConsultarQuatidadePCD.asp $>$. Acesso em: 10 mar. 2016.

34 BRASIL. Lei no 8.666, de 21 de junho de 1993. Regulamenta o art. 37, inciso XXI, da Constituição Federal, institui normas para licitações e contratos da Administração Pública e dá outras providências. Presidência da República. Disponível em: <http://www.planalto.gov.br/ccivil_03/Leis/L8666cons. $\mathrm{htm}>$. Acesso em: 14 fev. 2016.

35 (art. 104, do Estatuto da Pessoa com Deficiência) BRASIL. Lei no 13.146, de 6 de julho de 2015. Institui a Lei Brasileira de Inclusão da Pessoa com Deficiência (Estatuto da Pessoa com Deficiência). Presidência da República. Disponível em: <http:/www.planalto.gov.br/CCIVIL_03/_Ato2015-2018/2015/Lei/L13146. $\mathrm{htm} \geq$. Acesso em: 29 fev. 2016.

36 Idem.

37 INSTITUTO BRASILEIRO GEOGRAFIA E ESTATÍSTICA - IBGE. Censo 1991. Disponível em: <http://www.ibge.gov.br/home/estatistica/populacao/censodem/default_censo1991.shtm>. Acesso em: 1 mar. 2016.

38 BRASIL. Lei n ${ }^{\circ} 7.853$, de 24 de outubro de 1989. Dispõe sobre o apoio às pessoas portadoras de deficiência, sua integração social, sobre a Coordenadoria Nacional para Integração da Pessoa Portadora de Deficiência - Corde, institui a tutela jurisdicional de interesses coletivos ou difusos dessas pessoas, disciplina a atuação do Ministério Público, define crimes, e dá outras providências. Presidência da República. Disponível em: <http://www.planalto.gov.br/ccivil 03/Leis/L7853.htm>. Acesso em: 14 fev. 2016.

39 INSTITUTO BRASILEIRO GEOGRAF̄A E ESTATÍSTICA - IBGE. Censo 2000: dados preliminares. Rio de Janeiro: IBGE, 2000. Disponível em: <www.ibge.gov.br>. Acesso em: 29 fev. 2016.

40 Órgão elevado ao status de Subsecretaria Nacional de Promoção dos Direitos da Pessoa com Deficiência, criada por meio da Lei ${ }^{\circ} 11.958$, de 26 de junho de 2009 e do Decreto $\mathrm{N}^{\circ} 6.980$, de 13 de outubro de 2009, chegado ao status de Secretaria Nacional de Promoção dos Direitos das Pessoas com Deficiência por meio do Decreto $N^{\circ} 7.256 / 10$.

41 BRASIL. Lei no 7.853, de 24 de outubro de 1989. Dispóe sobre o apoio às pessoas portadoras de deficiência, sua integração social, sobre a Coordenadoria Nacional para Integração da Pessoa Portadora de Deficiência - Corde, institui a tutela jurisdicional de interesses coletivos ou difusos dessas pessoas, disciplina a atuação do Ministério Público, define crimes, e dá outras providências. Presidência da República. Disponível em: <http://www.planalto.gov.br/ccivil_03/Leis/L7853.htm Z. Acesso em: 14 fev. 2016. 
42 INSTITUTOBRASILEIRO DE GEOGRAFIAE ESTATÍSTICA - IBGE. Censo 2000: dados preliminares. Rio de Janeiro: IBGE, 2000. Disponível em: <www.ibge.gov.br>. Acesso em: 29 fev. 2016.

43 CENSO DEMOGRÁFICO 2010. Características da população e dos domicílios: resultados do universo. Rio de Janeiro: IBGE, 2011. Disponível em: <http://censo2010.ibge.gov.br/>. Acesso em: 29 fev. 2016.

44 Idem.

45 Idem.

46 Idem.

47 Idem.

48 BRASIL. Secretaria Nacional de Promoção dos Direitos da Pessoa com Deficiência. Disponível em: $<$ http://www.pessoacomdeficiencia.gov.br/app/node/765 $\geq$. Acesso em: 9 mar. 2016.

49 CENSO DEMOGRÁFICO 2010. Características da população e dos domicílios: resultados do universo. Rio de Janeiro: IBGE, 2011. Disponível em: < http://censo2010.ibge.gov.br/>. Acesso em: 29 fev. 2016

50 BRASIL. Decreto n ${ }^{\circ} 3.298$, de 20 de dezembro de 1999. Regulamenta a Lei no 7.853, de 24 de outubro de 1989, dispõe sobre a Política Nacional para a Integração da Pessoa Portadora de Deficiência, consolida as normas de proteção, e dá outras providências. Presidência da República. Disponível em: <http:// www.planalto.gov.br/ccivil_03/decreto/D3298.htm>. Acesso em: 14 fev. 2016.

51 Idem.

52 SCHWARZ, Andrea; HABER, Jaques. Cotas: como vencer os desafios da contratação de pessoas com deficiência. São Paulo: i.Social, 2009. Disponível em: <http://www.isocial.com.br/livro/versao-pdf.pdf>. Acesso em: 16 mar. 2016.

53 População do Ceará - 8.448.055; População do Brasil - 190.755.799 habitantes

54 BRASIL. Decreto n ${ }^{\circ} 3.298$, de 20 de dezembro de 1999. Regulamenta a Lei no 7.853, de 24 de outubro de 1989, dispõe sobre a Política Nacional para a Integração da Pessoa Portadora de Deficiência, consolida as normas de proteção, e dá outras providências. Presidência da República. Disponível em: <http:// www.planalto.gov.br/ccivil_03/decreto/D3298.htm >. Acesso em: 14 fev. 2016.

\title{
THE PATH TOWARDS THE INCLUSION OF PERSONS WITH DISABILITIES IN THE JOB MARKET: WHERE ARE WE?
}

\begin{abstract}
Over the last decades, international organizations, State bodies, non-governmental organizations and society as a whole have cast their gaze to the struggle waged by persons with disabilities, striving for social inclusion. A number of international documents were created, aiming not only to improve the living conditions of persons with disabilities, but also at incorporating social inclusion on the agenda. Every human being has the right to enjoy all the necessary conditions for the development of their talents and aspirations. Persons with disabilities should be provided with special conditions, in addition to the protection guaranteed to all, that minimize or eliminate the barriers to their life in society. The Convention on the Rights of Persons with Disabilities, ratified by Brazil, has as a main purpose to promote, protect and ensure the full enjoyment of Human Rights
\end{abstract}


by persons with disabilities, requiring legislative and administrative measures from State-Parties. Following several pieces of legislation addressing the issue, Brazil instituted its Brazilian Law of Inclusion of People with Disabilities (Statute of Persons with Disabilities). Despite its importance, legislation does not have the power to quickly transform the behavior of society. Public policies, as provided for in the Statute itself, are necessary to stimulate and monitor this process. The inclusion of persons with disabilities in the workplace is one of the most important aspects of this effort. Through numbers obtained by statistical systems already in existence, it is possible to analyze the degree of success, check where the flaws in public policies of inclusion are and suggest changes.

Keywords: Disability. Social Inclusion. Employment. Census. RAIS.

Submetido: 21 mar. 2016

Aprovado: 13 maio 2016 